\title{
Upaya Meningkatkan Aktivitas dan Hasil Belajar Matematika Melalui Model Pembelajaran Pencocokan Kartu Indeks pada Peserta Didik Kelas IX $\mathbf{S}$ SMP
}

Ismet

Guru SMP Negeri 3 Pasaman

\begin{abstract}
Abstrak
Pembelajaran matematika cenderung di laksanakan guru dengan pola memberi latihan setelah di jelaskan. Hal ini membuat pesertadidik kurang termotivasi untuk belajar. Hal ini terlihat dari nilai peserta didik berada di bawah KKM. Selainitu peserta didik cenderung tidak mau bertanya, terkadang setelah pahampun malas mengerjakan soal-soal latihan yang diberikan guru. Pada proses pembelajaran terlihat peserta didik jenuh dan bosan belajar matematika. Salah satu cara yang dapat dilakukan dengan menggunakan model pembelajaran Pencocokan Kartu Indeks. Tujuan penelitian ini mendapatkan gambaran tentang model pembelajaran pencocokkan kartu indeks pada peserta di dikkelas IX1 SMPN. Metode penelitian yang digunakan adalah tindakan kelas. Hasil dari penelitian ini adalah sebagai berikut: adanya peningkatan ketuntasan hasil belajar peserta didik dari siklus I ke siklus II yaitu $69 \%$ menjadi $77 \%$. Sedangkan jika ditinjau dari aktivitas peserta didik pada item peserta didik yang dapat menemukan pasangan dari $63 \%$ meningkat menjadi 69\%. Peserta didik yang mau memberikan kuis $77 \%$ menurun menjadi $71 \%$. Peserta didik yang mau menjawab pertanyaan dari peserta didik lain meningkat dari 74 menjadi $77 \%$. Sedangkan peserta didik dapat menjawab kuis dengan benar dari $77 \%$ meningkat menjadi $83 \%$. Hasil belajar peserta didik juga meningkat dari rata-rata 65 meningkat menjadi 75. Berdasarkan hasil penelitian dapat disimpulkan bahwa penerapan model pencocokan kartu indeks dapat meningkatkan beberapa aktivitas dan dapat meningkatkan hasil belajar matematika peserta didik.
\end{abstract}

Kata kunci: aktivitas belajar, hasil belajar dan model pembelajaran pencocokan kartu indeks

Copyright (C) 2016 IICET (Indonesia) - All Rights Reserved

Indonesian Institute for Counseling, Education and Theraphy (IICET)

\section{PENDAHULUAN}

Pendidikan merupakan hal penting yang harus dinikmati setiap warga negara Indonesia seperti yang tertuang dalam Undang- undang Dasar 1945. Menurut Tangkudung, G. F. C. (2016) pendidikan merupakan suatu hal yang fundamental dan mutlak harus dinikmati setiap insan, pendidikan membantu pengembangan potensi serta kemampuan agar bermanfaat dan kompeten sebagai individu dan masyarakat lainnya. Selanjutnya Ali, M. (2009) setiap warga negara wajib mengikuti pendidikan dasar dan pemerintah wajib membiayainya. Sependapat dengan Giyanto, B. (2008) pendidikan harus terjangkau oleh seluruh rakyat Indonesia. Kemudian Saefulloh, A. (2009) juga mengemukakan pendidikan dalam pandangan individu merupakan pengembangan potensi dan kreativitas, yang menggarap kekayaan yang ada dalam individu agar dapat dinikmati oelh dirinya. Apalagi pemerintah telah melaksanakan wajib belajar 12 tahun bagi anak-anak usia sekolah Bastian, I., \& Hadiwidjaja, R. D. (2014).

Melalui pendidikan diharapkan setiap warga negara berfikiran maju sehingga bisa bersaing di era globalisasi ini. Menurut Riza, S. (2008) pendidikan dapat emngarah pada pencapaian tingkat hidup yang lebih 
baik. Setiap wagra negara dituntut untuk bisa berkompetensi memacu diri agar tidak tergilas dan tertindas. Lembaga formal yang melaksanakan pendidikan adalah sekolah. Setiap warga negara berhak menyelenggarakan pendidikan berbasis masyarakat baik pendidikan formal maupun nonformal Nasional, S. P. (2003).

Sekolah bertanggung jawab terhadap perkembangan dan kemajuan anak didiknya. Menurut Sani, R. A. (2013) mengungkapkan guru meupakan tombak pendidikan seharusnya selalu berupaya melaksanakan yang terbaik dalam mendidik anak bangsa. Guru sebagai ujung tombak pendidikan berperan aktif dalam memajukan dan memacu kreatifitas anak didiknya. Selanjutnya menurut Murwani, E. D. (2006) guru dituntut untuk kreatif dan inovatif. Guru sebagai pendidik dituntut untuk mau dan mampu melaksanakan tugas dan perannya dalam mengelola, merencanakan dan melaksanakan pendidikan pada umumnya dan matematika khususnya. Kemudian Kependidikan, D. T., Jenderal, D., Kependidikan, P. M. P. D. T., \& Nasional, D. P. (2008) guru juga berperan sebagai pemberi informasi. Sependapat dengan Mahmudi, A. (2009), Subandowo, S. (2009) guru merupakan pendidik profesional dengan tugas utamanya mendidik.

Selain guru pembelajaran menjadi ujung tombak bagi tercapainya pendidikan yang berkualitas (Ningrum, E. 2009 ; Werdayanti, A. 2008). Menurut Sanaky, H. A. (2005) mengungkapkan guru sebagai pendidik bukan hanya mampu mentransfer pengetahuan, karna guru yang profesional dituntut untuk senantiasa meningkatkan kemampuan, wawasan dan keterampilan berfikir kritis, kreatif dan inovatif untuk menghasilkan keputusan.

Pemerintah tentu tidak tinggal diam, banyak hal yang dilakukan pemerintah dalam meningkatkan sumber daya manusia yang ditujukan langsung pada guru sebagai pendidik. Upaya nyata yang dilakukan pemerintah antara lain dengan adanya regulasi tentang kenaikan pangkat yang berkaitan dengan pengembangan diri, adanya wadah untuk pengembangan diri dalam forum MGMP ( Musyawarah Guru Mata Pelajaran), adanya tunjangan sertifikasi guru yang dikenal dengan tunjangan profesional, memberikan pelatihan- pelatihan, seminar dan lain-lain.

Namun kenyataanya masih jauh dari harapan khususnya pada mata pelajaran Matematika. Masih banyak nilai peserta didik berada dibawah KKM. KKM ini sudah disepakati dalam lokakarya di sekolah SMPN 3 Pasaman.Selainitu peserta didik cenderung tidak mau bertanya, terkadang setelah pahampun malas mengerjakan soal-soal latihan yang diberikan guru. Pada proses pembelajaranterlihat peserta didik jenuh dan bosan belajar matematika.

Permasalahan yang terjadidalampembelajaranmatematikadikelas IX I $_{1}$ SPN 3 Pasaman disebabkan beberapa faktor, diantaranya: peserta didik kurang aktif dalam belajar matematika sehingga materi yang dipelajarikurang dipahami. Hal ini terlihat sewaktu proses pembelajaran, guru belummenggunakan modelpembelajaran yang cocokuntukmaterimateri yang dipelajari. Hasiltes formatif peserta didik pada pelajaran matematika, seperti tertera pada tabel dibawah ini:

Tabel 1. Rata-Rata Tes Formatif Peserta Didik

\begin{tabular}{clccc}
\hline No & Kelas & Jumlah Peserta didik & Tes Formatif & Rata-rata \\
\hline 1. & $\mathrm{IX}_{1}$ & 27 & 1. & 68 \\
2. & & & 2. & 65 \\
\hline
\end{tabular}

Sumber : Arsip guru mata pelajaran matematika SMPN 3 Pasaman.

Masalah di atasperludiatasi agar tidak terjadi terus-menerus.Hal yang perludilakukanoleh guru memilih model pembelajarandenganmemperhatikan karakteristik materi matematika yang diajarkan dan karakteristik peserta didik. Guru perlu memilih dan menggunakan model, strategi atau motode yang bervariasi sehingga memudahkan peserta didik dalam mempelajari suatu topik dan mengerjakan soal-soal latihan sebagai pemantapan materi bagi peserta didik. PandanganbelajaraktifmenurutsalahsatuahliMelvin L Silbermen terjemahan Raisul Muttaqien (2006:23)menyatakanbahwa "saya dengar, saya lupa.Saya dengar dan lihat, saya sedikit ingat.Saya dengar, lihat dan pertanyakan atau diskusikan dengan orang lain, saya mulai paham.Saya dengar, lihat, bahas dan terapkan, saya dapatkan pengetahuan dan keterampilan. Saya ajarkan kepada orang lain saya kuasai". 
Berdasarkan pendapat tersebut dapat diketahui bahwa penguasaan peserta didik terhadap materi pembelajaran tergantung seberapa jauh keterlibatan langsung dalam pembelajaran tersebut. Guru hanya bersifat memfasilitasi peserta didik untuk menguasai materi pembelajaran tersebut.

Berdasarkan pendapat diatas guru sebagai ujung tombak pendidikan bagi peserta didik dituntut untuk dapat memilih dan menggunakan variasi terkait penggunaan model, strategi atau metode pembelajaran agar tujuan proses pembelajaran dapat tercapai secara optimal. Salah satu model yang dapat digunakan guru dalampembelajaranmatematikaadalah model pembelajaran pencocokan kartu indeks.

Model pembelajaran pencocokan kartu indeks merupakan cara-cara untuk mengakhiri sebuah pelajaran agar peserta didik mengingat apa yang telah dia pelajari dan memahami cara menerapkannya di masa mendatang.Dengan adanya model pembelajaran pencocokan kartu indeks diharapkan materimatematika yang dipelajaripeserta didik tidakmudah dilupakan.

Berdasarkan uraian di atas maka penelitian ini berjudul "Upaya Meningkatkan Aktivitas dan Hasil Belajar Matematika melalui Model Pembelajaran Pencocokan Kartu Indeks pada Peserta Didik Kelas IX 1 SMPN 3 Pasaman. Rumusan masalah dalam penelitian ini adaah "bagaimanakah model pembelajaran pencocokan kartu indeks dapat meningkatkan aktivitas dan hasil belajar Matematika peserta didik?" tujuan penelitian ini untuk mendapatkan gambaran tenatng model pembelajaran pencocockan kartu indeks pada peserta didik kelas IX1 SMPN 3 Pasaman.

\section{METODE PENELITIAN}

Penelitian ini menggunakan Penelitian Tindakan Kelas(Classroom Action Research) dikembangkan oleh Kemmis dan Mc. Taggart. Subyek penelitian ini adalah siswa kelas IX 1 SMP Negeri 3 Pasaman. Jumlah siswasebagaisubjekpenelitiansebanyak26 orang yang terdiri dari 14 laki-laki dan 12 perempuan.Penelitianinidilaksanakanpada tahun ajaran 2016-2017 semester I pada materi Peluang. Penelitian ini dilaksanakan sebanyak 2 siklus. Setiap siklus terdiridari 3 kali pertemuan. Untuk setiap pertemuan diadakan kuis. Kuis ini dilakukan untuk mendapatkan gambaran tentang pemahaman peserta didik terhadap materi yang dipelajari. Jika hasilnya belum memuaskan maka berlanjut pada siklus berikutnya.

\section{SIKLUS 1}

1. Persiapan

Beberapa hal yang perlu dipersiapkan adalah:

a. Guru menyiapkan RPP dan buku sumber

b. Guru menyiapkan bahan ajar.

c. Guru menyiapkan kartu indeks berisi soal dan jawaban

d. Menyiapkan soalkuisuntukmengetahui penguasaan pesertadidik terhadap materi matematika yang dipelajari.

2. Tindakan

Tindakan yang dilakukan pada penelitian ini adalah:

a. Guru menjelaskan materi Peluang.

b. uru menyiapkan kartu indeks (sebagian kartu berisi soal dan sebagiannya lagi berisi jawaban).

c. Guru mengocok semua kartu agar tercampur aduk.

d. Setiap peserta didik diberikan sebuah kartu indeks secara acak.

e. Guru mengintruksikan kepada peserta didik untuk mencari kartu pasangan mereka dan bila sudah terbentuk pasangan kartu peserta didik mencari tempat duduk bersama.

f. Bila semua pasangan yang cocok telah duduk bersama, perintahkan tiap pasangan untuk memberikan kuis kepada peserta didik yang lain dengan membacakan keras-keras pertanyaan mereka dan menantang peserta didik lain untuk memberikan jawaban.

g. Guru membimbing siswa mengambil kesimpulan.

h. Guru memberikan tugas sebagai pekerjaan rumah.

i. Setelah selesai satu pertemuan, pada pertemuan berikutnya dibagikan buku PR yang telah diperiksa.

j. Pada pertemuan berikutnya diawal pertemuan membahas PR

3. Pengamatan

Pengamatandilakukanoleh observer.Observer mencatat aktivitas belajar yang terjadi selama tindakan diberikan. 


\section{Refleksi}

Pada tahap ini, peneliti mendiskusikan hasil observasi dengan teman sejawat tentang aktivitas yang dilakukan peserta didik pada setiap pertemuan. Data yang digunakan adalah hasil lembaran observasi dan tes hasil belajar peserta didik yang terjadi pada siklus I. Jika hasilnya belum sesuai dengan yang diharapkan maka diadakan revisi tindakan pada siklus ke II.

\section{Hasil Penelitian dan Pembahasan \\ Hasil penelitian \\ siklus I}

Siklus I dilaksanakan selama 3 kali pertemuan dengan satu kali tes. Materi yang diberikan pada siklus I sebagai berikut:

Tabel 2. Materi Siklus I

\begin{tabular}{clll}
\hline $\begin{array}{c}\text { Pertemuan } \\
\text { ke }\end{array}$ & Pokok Bahasan & \multicolumn{1}{c}{ Sub Pokok Bahasan } & Waktu \\
\hline 1. & Statistika dan Peluang & Populasi dan Sampel & $2 \times 40$ \\
2. & Statistika dan Peluang & Penyajian data tunggal dan kelompok & $2 \times 40$ \\
3. & Statistika dan Peluang & Penyajian data dalam bentuk diagram & $2 \times 40$ \\
\hline
\end{tabular}

Sub pokokbahasaninimenjadimateri yang dipelajarisiswa. Berdasarkanhasilpembelajaran yang dilaksanakan, Aktivitas siswa dalam pembelajaran dapat dilihat pada table berikut ini.

Hasil yang diperoleh dari hasil observasi berupa aktivitas yang dilakukan peserta didik. Aktivitas yang menjadi fokus penelitian sebanyak empat jenis. Sajian data aktivitas ini dapat dilihat pada tabel berikut ini.

Tabel 3. Hasil Pengamatan Aktivitas Belajar Peserta Didik PadaSiklus I.

\begin{tabular}{|c|c|c|c|c|c|c|c|}
\hline \multirow[t]{3}{*}{ No } & \multirow[t]{3}{*}{ Aktivitas peserta yang diamati } & \multicolumn{6}{|c|}{ Hasil Pengamatan Pertemuan ke } \\
\hline & & \multicolumn{2}{|c|}{ I } & \multicolumn{2}{|c|}{ II } & \multicolumn{2}{|c|}{ III } \\
\hline & & $\mathrm{N}$ & $\mathrm{P}$ & $\mathrm{N}$ & $\mathrm{P}$ & $\mathrm{N}$ & $\mathrm{P}$ \\
\hline 1. & $\begin{array}{l}\text { Peserta didik yang dapat } \\
\text { menemukan pasangan kartu dan } \\
\text { duduk bersama }\end{array}$ & 16 & 62 & 18 & 69 & 16 & 62 \\
\hline 2. & $\begin{array}{l}\text { Peserta didik yang mau memberikan } \\
\text { kuis kepada peserta didiklainnya }\end{array}$ & 20 & 77 & 17 & 65 & 23 & 88 \\
\hline 3. & $\begin{array}{l}\text { Peserta didik yang mau menjawab } \\
\text { pertanyaan dari peserta didik lain }\end{array}$ & 19 & 73 & 20 & 77 & 19 & 73 \\
\hline 4. & $\begin{array}{l}\text { Peserta didik yang dapat menjawab } \\
\text { kuis dengan benar }\end{array}$ & 20 & 77 & 18 & 69 & 22 & 85 \\
\hline & Jumlah peserta didik hadir & & & & & & \\
\hline
\end{tabular}

\section{$\mathrm{N}=$ banyak siswa yang aktif}

$\mathrm{P}=\%$ peserta didik yang aktif

Tabel 3 diatas menunjukkan adanya aktivitas peserta didik yang meningkat tetapi ada pula yang turun.Aktivitaspeserta didik pada item 1"peserta didik yang dapat menemukan pasangan kartu dan duduk bersama"dan "peserta didik yang mau menjawab pertanyaan dari peserta didik lain" terjadi peningkatan pada pertemuan ke 2 tetapi menurun lagi pada pertemuan 3. Padaaktivitas "peserta didik yang mau memberikan kuis kepada peserta didiklainnya" dan "peserta didik yang dapat menjawab kuis dengan benar"terjadi penurunanaktivitaspadapertemuan ke-2.Padapertemuan ke-3 terjadilagipeningkatan.

Hasil belajar pada siklus Idiperoleh setelah selesai proses pembelajaran kemudian dilanjutkan dengan kuis dan 1 kali tes.Sajian data hasilbelajarpesertadidikpadasiklus I dapatdilihatpadatabelberikutini.

Tabel 4. Data nilai kuiz dan nilai tes matematika siklus I

\begin{tabular}{ccccccc}
\hline No & $\begin{array}{c}\text { Banyak } \\
\text { peserta }\end{array}$ & Nilai terendah & $\begin{array}{c}\text { Nilai } \\
\text { tertinggi }\end{array}$ & $\begin{array}{c}\text { Nilai } \\
\text { rata- rata }\end{array}$ & $\begin{array}{c}\text { Benyak } \\
\text { peserta } \\
\text { tuntas }\end{array}$ & $\begin{array}{c}\text { Persentase } \\
\text { Ketuntasan }\end{array}$ \\
\hline Kuiz I & 26 & 40 & 70 & 55 & 15 & 58 \\
Tes 1 & 26 & 40 & 80 & 65 & 18 & 69 \\
\hline
\end{tabular}


Nilai rata- rata yang diperoleh siswa saatdiadakan kuiz pada siklus I sebesar 55, peserta didik yang tuntas sebanyak 15 orang dengan persentase ketuntasan 58\%. Saat dilaksanakan tes, nilai rata-rata siswa terjadi peningkatan. Nialai rata-rata siswa saat dilaksanakan tes sebesar 65 dan persentase ketuntasan sebesar $69 \%$. Hasil observasi dan refleksi perlu diadakan perbaikan dalam pembelajaran agar tujuan pelaksanaan pembelajaran tercapai. Langkah perbaikan yang harus dilakukan pada diskusi kedua sebagai berikut.

a. Pasangan kartu dibuatberdasarkan kemampuan dan keaktifan peserta didik sehingga diharapkan semua kelompok aktif.

b. Sistempengambilankartudibalik. Jika pada siklus I peserta didik mendapat kartu pertanyaan maka pada siklus II mendapat kartu jawaban.

c. Bagi pasangan yang kurang aktif guru membimbing langsung pasangan tersebut.

\section{Siklus II}

Proses pembelajaran pada siklus kedua ini menggunakan materi ukuran pemusatan data. Materi ini merupakan lanjutan dari materi padasiklus I. Aktivitas siswayang diamati pada siklus II ini sama dengan aktivitas yang diamati pada siklus I. Data aktivitas peserta didik yang diamati di setiap pertemuan pada siklus II ini tergambar dari tabel dibawah ini.

Tabel 5. Aktivitas Belajar Peserta Didik Pada Siklus II

\begin{tabular}{|c|c|c|c|c|}
\hline Pertemuan ke & \multicolumn{2}{|c|}{ I } & \multicolumn{2}{|c|}{ II } \\
\hline Komponen yang diamati & $\mathrm{N}$ & $\mathrm{P}$ & $\mathrm{N}$ & $\mathrm{P}$ \\
\hline $\begin{array}{l}\text { Peserta didik yang dapat menemukan } \\
\text { pasangan kartu dan duduk bersama }\end{array}$ & 18 & 69 & 20 & 77 \\
\hline $\begin{array}{l}\text { Peserta didik yang mau memberikan kuis } \\
\text { kepada peserta didik }\end{array}$ & 17 & 65 & 20 & 77 \\
\hline $\begin{array}{l}\text { Peserta didik yang mau menjawab } \\
\text { pertanyaan dari peserta didik lain }\end{array}$ & 20 & 77 & 20 & 77 \\
\hline $\begin{array}{l}\text { Peserta didik yang dapat menjawab kuis } \\
\text { dengan benar }\end{array}$ & 21 & 81 & 22 & 85 \\
\hline Jumlah peserta didik yang hadir & & & & \\
\hline
\end{tabular}

Catatan :

$\mathrm{N}$ = Banyaknya peserta didik yang aktif

$\mathrm{P}=$ Persentase peserta didik yang aktif.

Pada tabel 5 terlihat pertemuam pertama padasiklus II ini, aktivitas "pesertadidik yang dapat menemukan pasangan kartu dan duduk bersama" sebesar 69\%. Aktivitas ini meningkat pada pertemuan ke-2 sebesar 77\%.Walaupun belum semua siswa dapat menemukan pasangan, paling tidak sudah ada peningkatan dari pertemuan sebelumnya. Untuk aktivitas lain sudah terlihat ada peningkatan. Aktivitas"peserta didik yang mau menjawab pertanyaan dari peserta didik lain" tidak terjadi peningkatan. Sedangkan aktivitas "pesertadidik yang dapat menjawab kuis dengan benar" cenderung menurun.

Hasil belajar pada siklus II terlihat pada table 6 berikut ini

Tabel 6. Nilai tes Matematika siklus II

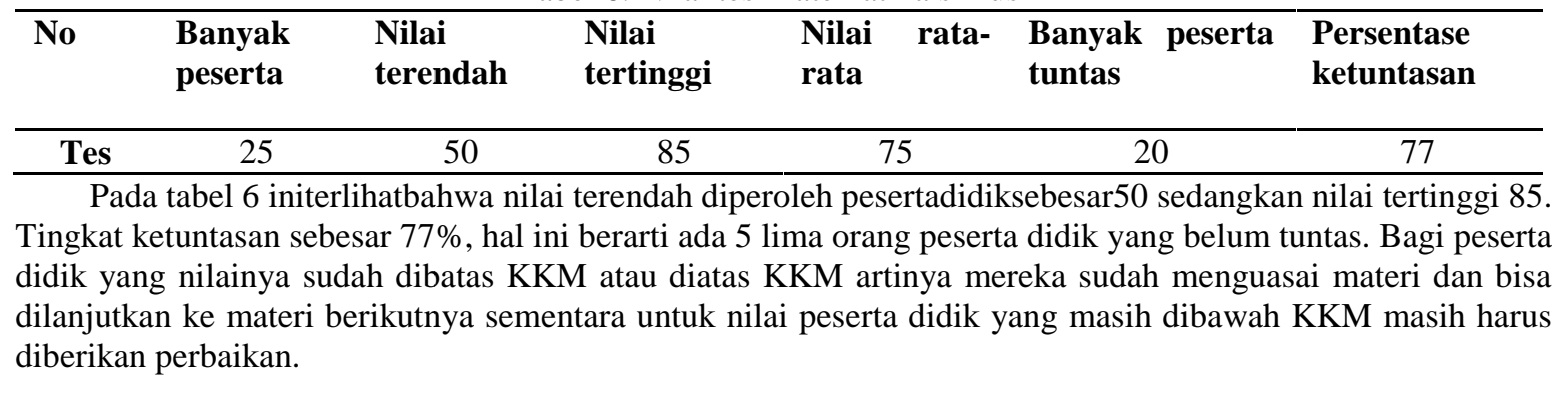




\section{Pembahasan}

Hasil analisis terhadap aktivitas belajar peserta didik bahwa masih terjadi aktivitas pesertadidik yang naik turun. Hal ini maksudnya adalah jumlah siswa melakukan aktivitas tersebut tidak konsisten. Pada pertemuan tertentu siswa sangat bersemangat, sedangkan pertemuan berikutnya belum tentu bersemangat. Sementara dalam proses pembelajaran diharapkan semua peserta didik terlibat secara aktif. Dari hasil pengamatan penelitian dan observasi di lapangan masih ada peserta didik yang duduk diam tanpa mau mencari pasangan sesuai kartu yang dimiliki, hal ini dikarenakan peserta didik belum terbiasa belajar aktif. Mereka biasanya hanya duduk diam mendengarkan keterangan dari guru. Pada aktivitas berikutnya terlihat peserta didik masihadayang belum terbiasa dan mereka masih kebingungan mencari pasangan saat kelas terlihat riuh dan ribut, tapi kebahagian tergambar dari raut wajahmereka. Padasiklus I, terdapatsatu orang peserta didik terlihat hanya duduk diam, hal ini disebabkan karena peserta didik tersebut sedang sakit.

Kuiz yang diberikan kepada peserta didik sebagai gambaran pemahaman mereka terhadap materi yang diberikan. Gambaran hasil belajar yang dilakukan melalu ites, terlihat adanya peningkatan rata-rata nilai siswa. Hal ini membutikan bahwa siswa sudah dapat memahami materi pembelajaran dengan baik. Ada sekitar 5 orang pesertadidik yang belum tuntas dalam mempelajari materi pembelajaran matematika. Setelah dianalisis diketahui bahwa ada peserta didik yang sedang sakit sehingga kurang konsentrasi dalam belajar dan mengikuti tes. Ada juga peserta didik yang kehadirannya tidak lengkap saat pembelajaran baik pada siklus I maupun pada siklus II. Hal ini menyebabkan materi yang di milikinya tidak utuh dan proses pembelajaran tidak lengkap diikutinya.

Hasil tes yang diperoleh pada siklus I dan siklus II perbandingannyadapatdilihatpada tabel berikut ini:

Tabel 7. Perbandingan HasilBelajarMatematika Peserta Didik Siklus I dan Siklus II

\begin{tabular}{cccc}
\hline Nilai & Siklus I & Siklus II & Keterangan \\
\hline Nilai terendah & 40 & 50 & meningkat \\
Nilai tertinggi & 80 & 85 & meningkat \\
Nilai rata- rata & 65 & 75 & meningkat \\
Persentase ketuntasan & 69 & 77 & meningkat \\
\hline
\end{tabular}

Pada tabel 7 terlihathasil belajar peserta didik. Adanyapeningkatanketuntasanbelajarpesertadidiksebesar 8\%.Hal inimemperlihatkanbahwapenggunaankartuindeksadalampembelajaranmatematikacukupberhasil.Nilai rata-rata pesertajugameningkatsebesar 10 poin.Begitujuganilaitertinggidanterendahterjadijugapeningkatan yang cukuptinggi. Hasil pengamatan dari observer terhadap proses pembelajaranpada penelitian ini tergambar perbandingan aktivitas belajar peserta didik seperti yang terdapat pada tabel dibawah ini.

Tabel 8. Perbandingan aktivitas belajar peserta didik antar siklus I dengan siklus II

\begin{tabular}{llccc}
\hline No & Aktivitas yang diamati & $\begin{array}{l}\text { Siklus I } \\
\text { (dalam \%) }\end{array}$ & $\begin{array}{l}\text { Siklus II } \\
\text { (dalam \%) }\end{array}$ & Keterangan \\
\hline 1. & $\begin{array}{l}\text { Peserta didik yang dapat menemukan } \\
\text { pasangan kartu dan duduk bersama }\end{array}$ & 62 & 78 & meningkat \\
2. & $\begin{array}{l}\text { Peserta didik yang mau memberikan kuis } \\
\text { kepada peserta didik }\end{array}$ & 77 & 71 & Menurun \\
3. & $\begin{array}{l}\text { Peserta didik yang mau menjawab } \\
\text { pertanyaan dari peserta didik lain }\end{array}$ & 74 & 77 & meningkat \\
$\mathbf{4}$ & $\begin{array}{l}\text { Peserta didik yang dapat menjawab kuis } \\
\text { dengan benar }\end{array}$ & 77 & 83 & meningkat \\
\hline
\end{tabular}

Dari tabel 8 dapat terlihat perbandingan rata-rata setiap komponen aktivitas pesertadidikyang diamati. Untuk setiap komponen mengalami peningkatan walau hanya sedikit.Sedangkanaktivitas "pesertadidik yang maumemberikankuiskepadapesertadidiklainnya" mengalamipenurunan.Tabel 8 diatas dapat digambarkan dengan diagram batang seperti berikut: 


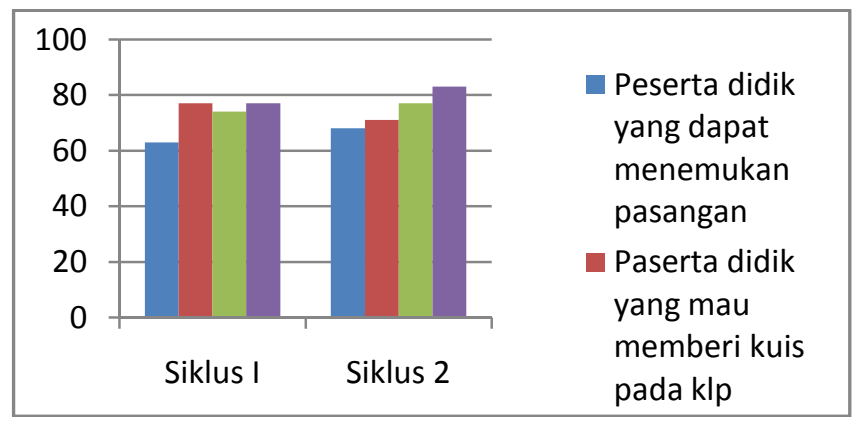

\section{SIMPULAN}

Gambar 1. PerbandinganAktivitasBelajarPesertaDidik

1. Penerapan model pembelajaran Pencocokan kartu indeks dapat meningkatkan aktivitas belajar peserta didik

2. Dengan adanya model pembelajaran Pencocokan kartu indeks dapat meningkatkan persentase ketuntasan

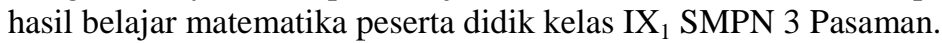

\section{SARAN}

1. Untuk meningkatkan aktivitas dan hasil belajar peserta didik maka peneliti menyarankan agar guru matematika dapatmenggunakanmodel pembelajaranmenggunakankartuindeksinipadamateri yang lain.

2. Membuatpasanganpesertadidiksebaiknyadiperhatikantingkatkemampuanmasing-masing.

\section{Referensi}

Ali, M. (2009). Pendidikan untuk pembangunan nasional: menuju bangsa Indonesia yang mandiri dan berdaya saing tinggi. Grasindo.

Arikunto, Suharsimi. 2003. Dasar- dasar Evaluasi Pendidikan. Jakarta: Universitas.

Almash, Lutfian. 1998. Pedoman Penelitian Tindakan Kelas. Padang: IKIP Padang.

Bastian, I., \& Hadiwidjaja, R. D. (2014). Laboraturium Akuntansi Pendidikan.

Fauzan, Ahmad. 2008. Modul Proses Pembelajaran Matematika. UNP Padang.

Giyanto, B. (2008). STATEGI PENANGGULANGAN KEMISKINAN (STUDI KASUS DKI JAKARTA). Jurnal Borneo Administrator, 4(2).

Kependidikan, D. T., JENDERAL, D., KEPENDIDIKAN, P. M. P. D. T., \& NASIONAL, D. P. (2008). Strategi Pembelajaran MIPA. Jakarta: Departemen Pendidikan Nasional.

Mahmudi, A. (2009). Mengembangkan Kompetensi Guru Melalui Lesson Study. In Jurnal Forum Kependidikan FKIP UNSRI (Vol. 28).

Murwani, E. D. (2006). Peran guru dalam membangun kesadaran kritis siswa. Jurnal Pendidikan Penabur, 6 , 59-68.

Nasional, S. P. (2003). Undang-undang republik Indonesia nomor 20 tahun 2003. Jakarta, Depertemen Pendidikan Nasional Republik Indonesia.

Ningrum, E. (2009). Kompetensi Profesional Guru dalam Konteks Strategi Pembelajaran. Bandung: Buana Nusantara.

Riza, S. (2008). Konsep Pendidikan Islam Menurut Pemikiran Ibn Khaldun: Suatu Kajian Terhadap ElemenElemen Kemasyarakatan Islam [BP174. S984 2008 f rb] (Doctoral dissertation, Universiti Sains Malaysia).

Saefulloh, A. (2009). Membaca "Paradigma" Pendidikan dalam Bingkai Multikulturalisme. Insania, 14(3), 547-559.

Sanaky, H. A. (2005). Sertifikasi dan profesionalisme guru Di era reformasi pendidikan. Jurnal Pendidikan Islam, 1, 1-13.

Sani, R. A. (2013). Inovasi pembelajaran. Jakarta: Bumi Aksara.

Silbermen, Melvin L. 2006. Active Learning. Bandung: Nuansa.

Slameto. 1995. Belajar Dan Faktor- Faktor yang Mempengaruhinya. Jakarta:Rineka Cipta

Subandowo, S. (2009). Peningkatan Produktivitas Guru dan Lembaga Pendidikan Tenaga Kependidikan pada Era Global. KHASANAH PENDIDIKAN, 1(2).

Tangkudung, G. F. C. (2016). AKTUALISASI NILAI BUDAYA SEI REEN DALAM ASPEK PENDIDIKAN PADA MASYARAKAT TONDANO. JURNAL HOLISTIK.

Werdayanti, A. (2008). Pengaruh Kompetensi Guru Dalam Proses Belajar Mengajar Di Kelas dan Fasilitas Guru Terhadap Motivasi Belajar Siswa. Dinamika Pendidikan, 3(1). 